\title{
Value Stream Mapping in Enhancing Operational Performance of Ghanaian Food ProcessingIndustry: Mediating Role of Supply Chain Collaboration
}

\author{
Gloria Pokuaa-Duah \\ Putra Business School \\ Level 3 Office Building of The Deputy Vice Chancellor (Research and Innovation) \\ University Putra Malaysia \\ 43400 Serdang \\ Selangor \\ Malaysia \\ Devika Nadarajah \\ Putra Business School \\ Level 4 Office Building of The Deputy Vice Chancellor (Research and Innovation) \\ University Putra Malaysia \\ 43400 Serdang \\ Selangor \\ Malaysia
}

\begin{abstract}
Purpose - In today's competitive market, satisfying the customer demands that, the food processing industry (FPI) has to adopt constant process improvement strategies so as to retain a recurring customer base.Value stream mapping (VSM) adoption has been cited as one of the meansthrough which FPI can achieve constant process improvement. It is recognized as one of the efficient lean supply chain management (LSCM) tools for waste identification and elimination inmaterials and information flow, people as well as performance improvement among firms. The purpose of this paper is to assess effect of VSM on operational performance (waste reduction and elimination, product quality), the mediating role of supply chain collaboration (SCC).

Design/methodology/approach - This conceptual paper recommends an inclusive model that incorporate VSM, SCC dimensions and operational performance. Underpinned by theories such as the Dynamic Capabilities (DCT) and Relational View (RV), the proposed model is to establish the direct and indirect effects of VSM (multiplicative stages; identification of the product family, create a current state value stream map, future state value stream map, as well as implementation and performance comparison)on operational performance through the influence of SCC in the FPI context. The framework identifies, internal and external firm collaboration as the main goal of VSM implementation which will subsequently lead to improvements in operational performance.

Originality:The study effectively combines the DCT and RV to develop a comprehensive model involving three broad operations and supply chain management concepts. Though there may be similar studies on VSM practices among manufacturing industry, however, none of such a model or work that has been reported particularly in the context of Ghana especially FPI. Additionally, exploring the mediating roles of individual dimensions of SCC in the VSM practices - operational performance in the FPI is a novelty as it provides deeper insights on the mediating effects of each dimension of SCC in the relationship between VSM practices and operational performance. The proposed theoretical model is also a potential blueprint for successful LSCM practices implementation.
\end{abstract}

Keywords: Lean supply chain management (LSCM) approach,Value stream mapping (VSM), Operational performance, Supply chain collaboration

\subsection{Introduction}

According to World Economic Forum report (2016), the world will feed approximately 9 billion people by year 2050 since the demand for food is likely to rise by sixty percent greater than it is today. Studies have shown that the Food Processing Industry (FPI) has been marked as one of the fastest emerging industries all over the world (Ali, 2016), as every year, trillions of dollar worth of processed food products are produce, imported and sold all over the world (Kearney, 2010; Committee for Economic Development, 2017). For instance, the United States of America (USA) has been cited as one of the world's biggest economies that imports food products. 
In 2017, Cago, (2017) revealed that, the USA that imported a total of $\$ 133$ billion USD worth of food and food products, followed by China at $\$ 105.26$ billion USD, Germany at $\$ 98.90$ billion USD, Japan at $\$ 68.86$ billion USD, the United Kingdom at $\$ 66.54$ billion USD, the Netherlands at $\$ 64.38$ billion USD, France at $\$ 62.29$ billion USD, Italy at $\$ 51.34$ billion USD, Belgium at $\$ 40.87$ billion USD, and the Russian Federation at $\$ 38.60$ billion USD. This has forced manufacturersin FPIto come out with food products with the highest quality that can sufficiently meet the customers' demand (Hasnan, Aziz, Zulkifli \& Taip, 2014) thereby granting them survival in today's competitive market.

Prior studies have disclosed that, nearly half of the total food produced worldwide are wasted away (Fox \&Fimeche, 2013) i.e. more than one-third or two-thirds ( 1.3 billion tons of edible food)of food produced is lost or wasted along the supply chain (SC) (Dora, Kumar, \&Gellynck, 2016; FAO, 2018) due factors such as low value-addition in processing, lack of resource, skills and knowledge, low consumer demand awareness, lack of transparency, as well as demandsupply mismatches and distortions (Mukherjee et al., 2013), overproduction and processing, defects (Halloran et al., 2014), negligence of SC members with respect to handling methods, and machine failures leading to faulty packaging as well as firms' (internal and external) inability to adhere to material or product specifications in terms of quality, looks, smell and taste (Dora et al., 2019). Food waste (FW)can be explained as food loss that occurs at the end of the food supply chain (FSC) in the retail and final consumption stages (Parfitt, Barthel and Macnaughton, 2010).

The Ghanaian FPI is a subset of the manufacturing industry, an important sector that contributes to the growth of the economy in areas such as provision of food which is its basic mandate, employment creation, and generating a significant revenue for the country through exports (Andam \& Asante, 2018). For instance,in 2017, the sector accounted for about 42 percent of the country's manufacturing output, created about 40 percent employment opportunities and exported processed foods to almost 15 countries worldwide with an annual export value of more than $\notin 7.9344$ trillion ( $\$ 1.7632$ billion), which amounted two-thirds of the total food exports of over $\$ 13.68$ trillion; however, the sector is often affected by a lot wastages due to some distinct features such as perishability, a short shelf life, seasonality, and varied harvesting conditions (Tanco et al., 2013); this sometimes result in low performance of FPI (Heller \& Keoleian, 2015)hence an opportunity for process improvement(OECD, 2017).

Studies have summarized the traits of the FPI into three components: the product, production process, and manufacturing plant (Van Wezel, Van Donk, \&Gaalman 2006; Wang, Li, \& O’Brien 2009; Dora et al., 2016). Activities of FPI is associated with perishability such as raw materials or semi- and fully finished products as well as variability in terms of the quality, supply, and price due to an unpredictable yield. From the perspective of production process, the production yield, processing time, as well as product structure are all variable, with high disparities in the composition, formulas, products, and processing methods. The production rate is highly capacity reliance. For instance, in the FPI, the plant tends to exhibit a flow shop-oriented design, with the processing and packaging sectors being separated due to quality control requirements. Therefore, these factors make processing activities sensitive to time and the conditions during the production, making it easy to increase waste(Yuvamitra, Lee \& Dong, 2017).

Food wastages in Ghana according to OECD (2017) constitutes about 40 percent and studies have attributedFW to factors such as inadequate and poor business processes, technical skills and competence, as well as lack of collaboration among supply chain partners that tend to affect performance such as quality products that meet international standards for both local and foreign consumption (Owoo and Lambon-Quayefio 2015; ITC, 2016). According to Andam et al (2015), FW (unprocessed) alone constituted about 44 percent whereas importation, partially and packaged as well as completely processed food product were 39, 9 and 8 percent respectively. Experts have suggestedfor the committed efforts of SC partners towards the adoption and implementation of sustainable business strategies such lean supply chain management (LSCM) practicesnot only ensure reduction in waste or non-value addition (NVA), but to enable them improve performance of their organizations in terms of producing quality products whiles retaining their survival in the current competitive market (Tortorella et al., 2019). This is because, LSCM practices has been cited as a potential strategy that can assist firms to review and continuously improve their processes and operation to minimizeNVA and also put efficiency into material flow as well as integrate information among supply chain partners in producing product or service at the request of the customer to meet his/her expectation (Dharni \& Rodrigue 2015; Nimeh et al., 2018).

LSCM practices such as value stream mapping (VSM) according to prior studies is capable of increasing the effectiveness of value chain analysis byimproving consumer value at each stage (Zokaei\& Simons, 2006; Dadashnejad \&Valmohammadi, 2018). It ensures all wasteare eliminated or reducedby thoroughly outlining and restructuring all business processes into a single continuous flow while improving resource use which enhances firms' ability to meet unplanned challenges (Green, Lee \& Kozman, 2010). 
Waste is termed as non-value addition (NVA) activities in production such as defects, overproduction, inappropriate processing, unnecessary inventory, unnecessary motion, transport and waiting (Ohno, 1943).VSM can decrease firms' lead and production times by smoothing production to minimize NVA as well as improve the quality of a product (Boonsthonsatit \& Jungthawan, 2015; Dadashnejad \&Valmohammadi, 2018). It has been designed to map out all activities (both value and NVA) in value stream of production process, giving firms the chance to analyze the flow of raw material from suppliers to end customer thereby making it useful for decision making in leveraging competitiveness which is also key to flexibility as measured in with lead time (Modi \& Thakkar, 2014). It therefore promotes the usefulness of collaboration in the manufacturing environment i.e. managing quality within the value chain thereby improving food production and service (Ahmed et al., 2015), reduce operational cost, inculcate agility and meet the demands of their customers (Shrafat \& Ismail, 2018).

Although previous studies justify its usage in various industries as a tool to control NVA and improve performance of firms; Boonsthonsatit \& Jungthawan (2015) value addition, profits and cost reduction in the automobile industry, Steur et al (2016) reduction in food loss and waste in the FSC, Shou et al (2017) reduction in inventory, lead time, cycle time and manpower among manufacturing firms, Andreadis, Garza-Reyes and Kumar (2017) managerial practice in relation to operational performance such as reduction in lead and cycle time, inventory and productivity, Dadashnejad \&Valmohammadi (2018) production process improvement, higher customer satisfaction as result of cost reduction and quality enhancement yet limited studies have explored its applicability in FPI more especially in the Ghanaian context with a specific connection to waste reduction and enhancement in product quality through the influence of supply chain collaboration.This is because, most of the NVA or waste sometimes occur in different stages in value chain, therefore Steur et al (2016) suggest that it will be essential if future studies dealing with VSM could include at least one supply chain actorwith respect to performance improvements such as waste reduction and product quality. Given such importance of FPI in the Ghanaian economy, continued research is defensible to generate updated knowledge that can be useful in solving challenges experienced in the industry and to make meaningful decisions necessary for its further growth and success. Therefore, the purpose of this study is investigate the effectof the adoption and implementation of VSM in improving organizational performance of FPI.

\subsection{Literature Review}

\subsection{Operational Performance}

Operational performance measures the expectations of consumers or customers of a firm with respect to achieving satisfaction, providing value to customers, retaining customers base, and attaining a desired market share (Gupta \&Malhotra, 2013; Payne \& Frow, 2014) or the useof key indicators such as productivity, quick response to market changes, timely delivery, product quality, flexibility, unit manufacturing cost, lead time, scrap and rework cost, waste reduction (Shah \& Ward 2003; Bortolotti et al., 2014; Shrafat \& Ismail, 2018). According to researchers, competition, changes in customer taste and preference, rapid inventions and increase in technology are among the main cause of short product life cycle (Gan et al., 2015). A product is termed as the most essential item that the customer derives value from. A product's quality is related to customers' satisfaction level, because it has great influence on the product or service performance and customers will perceive it directly after using it (Sun et al., 2019). The quality of product or service should be able to withstand and take longer time to malfunction compare to that of rival (Fawcett et al., 2007; Williams, 2013).In a situation where these features are considered not to be present in an organization's product or service or does not meet all requirements, a low or poor level of quality is achieved (Praxiom Research Group Limited, 2010) and can also be termed as waste.

According to Hines and Rich (1997), operations of manufacturing can be categorized into three main fields; non-valueadding (NVA) activities, necessary but non-value-adding (NNVA) activities (waste) and value adding (VA) activities. NVA (waste) are actions that take resources yet bring no important to the both customer as well as organization, hence need to be eradicated. They includes unnecessary material handling, backtracking, waiting time, etc. NNVA though considered as waste by the customer, however might be important to the firm in order to complete its operational routines. These activities may be difficult to remove in short term as it might need key alterations in the existing operational procedures. Example might be walking long distances to pick up under-processed parts, unpacking inventories, etc. whereas VA activities include the operation like transformation of input into useful end product. The customers recognize these activities as valuable and therefore are willing to pay for it. These include machining of materials, forging of sub-parts, joining of sub-assemblies, etc. Base on the five principles of lean, value VSM conveys the possibility of firms identifying VA or NNVA activities and constantly pursues the goal of NVA elimination with the aim of increasing what is perceived as value in the eyes of the customer and redirects the workflow from a customer's perspective; i.e. a process that provides effective ways of instituting strategic directions for better decision making and work design ( $\mathrm{Li}, 2014)$. 
FPI with an enormous competitive market demands need to adopt contemporary and creative manufacturing practices that can sustain and improve the total attractiveness and productivity heights. LSCM practice follows the principle of lean thinking, which stresses on the reduction of waste and stoppage in the provision flow of goods, services and technologies from suppliers to customers. Thus, the 'lean thinking' and subsequent LSC adopt various management techniques and practices such as VSM to reduce overall costs, waste, enhance product quality, and shorten delivery times (Boonsthonsatit \& Jungthawan 2015; Shah \& Ganji, 2017). VSM has been cited as driving force concerning the enhancement of operational performance(waste reduction and elimination, product quality (Shah\& Ganji, 2017; Dadashnejad \&Valmohammadi, 2018), since it seeks to decrease performance time disparity by establishing standard work procedures.

\subsection{Value Stream Mapping}

The term "value stream" was first used in a book called "The Machine that Changed the World" in the 1990s which was written by James Womack, Daniel Jones, and Daniel Roos. It was further simplified into another book, "Lean Thinking," in 1996 by James Womack and Daniel Jones. These books essentially introduced the Lean movement. They defined the value stream as "the sequence of activities a firm undertakes to deliver on a customer's request." VSM can be traced back to more than 30 years ago, when it was known as the "material and information flow" and was used by Toyota Motor Corporation as a visual mapping technique to gain a better understanding in the flow material and information throughout the entire company (Manos, 2006). The popularity of VSM grew as the American companies observed and studied its efficiency and consistency in Toyotas' operations. As the Lean movement took off, so did this mapping technique that Toyota had developed and has continued to evolve to become what is now known as VSM, which is much more applicable and useful for businesses and value streams of all types(Rother and Shook, 1999; Yuvamitra et al., 2017).

VSM as a practice of lean has been recognized as a strategy that can create permanent value for any business in terms of product quality improvement (Jimenez et al., 2011; Dadashnejad \&Valmohammadi, 2018), since it can serve as references for firmsin the removal or decreasing unnecessary inventory and other sources of waste in the value chain, thereby achieving cost reduction and additional value-enhanced products (Lehtinen and Torkko 2005). Further, it can assist in visualizing how production system works from the time a customer plays a requisition till the time of delivery (Shararah, 2013). Hence, firms are able to gain a better appreciation of issues such as identification of problem (waste), hotspots where they occur, where value needs to be added or not, and more especially, how to enhance the cooperative process both internally and externally (Steur et al., 2016). Rother and Shook (1999) refer to VSM as a pencil and paper tool that supports the understanding of information and material flow throughout the production process of a product. It explains all activities and events (both VA and NVA) that a product or service passes through on its way from supplier to customer. Thus a tool used to design, analyze or map out VA and NVA in the production process by examining how the flow of raw material and information are related(Kilpatrick and Osborne, 2014).On the whole, Rother and Shook (1999) recommend four stage activities that should guide the implementation of VSM in any industry and this include; identification of the product family, create a current state value stream map, future state value stream map, as well as implementation and performance comparison.

\subsubsection{Identification of the Product Family (Problem)}

The first step in VSM is the identification of the product family. FPI have several product categories that undergo different processing stages, therefore Rother and Shook (1999; Garza-Reyes et al., 2018) caution against the mapping of all product families at once, as this can only make the VSM complicated. Womack (2006) remarks that carefully choosing a product family for VSM would increase the benefits expected from the VSM analysis. The identification stage will enable the FPIto determine its hotspot or the start and end points of the mapping exercise. For example, will the starting point be the creation of a customer feature request, will itstart with an approved request, end with a delivered product to production, or will you end with production side when the customer signs-off (Saboo et al., 2014). This also stage aids in VSM team(cross-sectional) selectionand mapping details; as team selection needs to be those individuals that are directly able to make the changes that might come from the activity so as achieve the objectives of the VSM activity (Brunt, 2000; Garza-Reyes et al., 2016)

\subsubsection{Developing Current State Value Steam Map}

The second step in VSM is to map the current state of the value stream. This should be done base on the agreement of problem statement and formation of a cross-functional team with representation from all departments (Rother and Shook, 1999; Lovelle, 2001). This stage may include additional processes and corresponding data such as the current cycle times, lead time, up time, takt times, SLA's etc. Once the current state of VSM has been created, the crosssectional team has to develop the target state VSM or walk through the value stream to draw a map of the process such as quality, delivery, waste removal, compliance or combination of any of these (Jeyaraj et al., 2013). 
This wouldempowerthe team to gain better understanding of the entire process (material and information flow) as well as have productive discussions such as what-if's and to develop better solutions to identified hot points (Jeong\&Yoon, 2016). The current state VSM is very essential as it comes in handy in the future, after changes have been implemented.The aim is to provide the firm a means through which before and after comparison of the process can be made, i.e.a performance figures to know whether changes had yield the desired results (Dadashnejad \&Valmohammadi, 2018). Yuvamitra et al (2017) affirmthe criticality of an accurate mapping of the current state since it ensuresthat, the future state and any recommendations or structural changes for improvement will begrounded on it.

\subsubsection{Creating Future State Value Steam Map}

Developing the proposed future state value stream map marks the third stage in the VSM and this is normally done based on current state VSM analysis. It is necessary for firms to identify areas that are termed as hotspots, bottlenecks, backlogs, strengths, and weaknesses in VSM where improvements and modifications are needed base on takt time, cycle times, lead time, up time etc. (Jeong\& Yoon, 2016). According to Jeong and Yoon (2016), the team has to identify gaps or improvement areas such as large inventories, long lead/cycle time, and defects, then give justifications on how and why these activities have been termed as NVA or waste. Yuvamitra, et al (2017) posit that future state map result in change processes, strategies and structures based on gaps identified.The development of future state map using lean principles can result in a number of modifications such as reduction of NVA activities and process improvements. Studies have revealed that drawing the future state map is very important because it ensures continuous flow through many activities and at the same time reduces costs, waste, throughput timeas well asimprove production process. This result in mutual benefits for both the firm and the customer (Womack, 2006; Tyagi et al., 2015; Dadashnejad \&Valmohammadi, 2018).

\subsubsection{Implementation and Performance Comparison}

This stage is deemed the final step in VSM. Once the future state value stream map is set, it truly represents the 'ideal' state in which the value stream should operate. The essence of this stage in VSM is to convert and executethemodifications and improvements to close the gap between the future state and current state (Rother and Shook, 1999; Dadashnejad \&Valmohammadi, 2018). For instance Saboo et al (2014) propose the use of lean tools and techniques to execute modification or recommendation in the ideal situation base on the current state as affirmed by Dadashnejad and Valmohammadi (2018) in achieving better results such as improvement in production process, customer satisfaction, cost reduction, waste and quality.

\subsection{Value Stream Mapping and Operational Performance}

Research suggest that by using VSM, organizations can decrease their lead time and production time by smoothing their production in order to decrease waste and improve the quality of a product. VSM can help FPI to reduce operational cost,inculcate agility and meet the demands of their customers (Kanyanya 2013; Shah and Ganji, 2017; Shrafat and Ismail, 2018). For instance, Boonsthonsatit \& Jungthawan (2015) revealed that VSM enables industries to maximize value addition, profits and improve operational performance such as cost and waste reduction.Steur et al (2016) contend that VSM has the potentials to improvethe visibility of the entire value stream (i.e. identification of food loss and waste hotspots) and subsequently creates an avenue for informationsharing which will definitely help to reduce food loss and waste in an integrated food system(i.e. multi-stakeholder approach relevant for supply chain management). Additionally, Nowak, Pfaff and Karbach (2017) revealed significant effect of VSM on the time dimension of process and quality outcomes because of its capacity to reduce non-value-added time (e.g., waiting time) and length of stay. Moreso, Shah and Ganji (2017) reported its frequent use to design, map out or analyze all action as well as its positive impact on the performance of the organizations. Yuvamitra et al (2017)suggested that VSM ensures waste elimination and structural revision, leading to efficient manufacturing process, and also enabling the customer to receive order significantly faster as affirmed by Dadashnejad and Valmohammadi (2018) in production process improvement, in terms of higher customer satisfaction due to cost decreases and quality improvement. It further operational performance such as equipment failures, set-up and changeovers, idling and minor stoppages, reduced speed operation, scrap and rework and startup losses. However, others like Belekoukias et al., (2014) cited its lesser usage, or even negative effect operational performance whereas Dal-Forno et al (2014) have critiqued the way and manner it has been used, observing that important constraints created by its application must be careful looked as incorrect usage, can lead to mistakes that can cause problems instead of benefits more especially at the problem identification stage where much understanding and classification of problem is more important.

\subsection{Supply Chain Collaboration and Organizational Performance}

Business is growing more competitive every day. Therefore in order to keep up with customer demand and expectations, it is necessary for firms to build intra and inter firm collaboration to work faster and be more efficient than ever before. 
Efficient supply chain collaboration (SCC) places all essential resources of all cooperative partners together and connects all functional processes so as to effectively utilize the resources (Zhang et al., 2015).Adopting intra and inter collaborative practices will enable firms to remain significant, improve performance and stay in business (Kraus et al., 2012). Liao et al. (2017) refer to collaboration as a situation where more than two partners' work together with the aim of completing jobs and ultimately attaining mutual objectives while SCC is defined as a long term relationship where individuals liaise, share information, and work together to strategize and even adjust their business processes to mutually enhance their performance(Whipple et al., 2010).Internal collaboration refers to as the degree to which manufacturers organizes their own firms' methods, practices and processes into a collective, synchronized processes, in order to realize their customers' requests and proficiently interact with their suppliers (Flynn et al., 2010) whereas external collaboration explains a firm's cooperation with or extension of firms operations to external chain partners such customers and suppliers (upstream and downstream members) to jointly streamline processes through sharing of vital information, knowledge as well as collaborative communication to improve performance (Cao \& Zhang, 2011; Nimeh et al., 2018). For instance Han et al. (2013) presented positive and significant relationship between internal collaborationwith respect to cross-functional cooperation in developing joint strategies and setting objectives, sharing information and working together to solve problems and firm performance (customer satisfaction, product quality, market share, sale growth and profitability). Moreso, Xu, Huo and Sun (2014) penned significant relationship between intra-organizational variable such top management support (TMS) and information technology (IT) influence supply chain integration (supplier and customer; information and involvement), which eventually affect business performance, even though both supplier and customer collaboration exert their influence in different ways. Kim and Chai (2016) reveal a positive relationship between internal and external chain collaboration on firms performance especially where changes in the market (dynamisms) and competition in the market (hostility) are very intense. Additionally, Cui and $\mathrm{Wu}$ (2016) postulate that SCC (firm-customer)ensures dissemination of important knowledge and information on product and process, which can lead to improvement in productivity product quality as well as market share. Haque and Islam (2018) affirm that inter-firm (firm and supplier) collaborations in areas such as demand planning prevents errors associated with forecasting, which eventually help meet customers' expectation such as product quality, nonetheless, Yuen and Thai (2017) content thatinternal and external collaboration differ with respect to theproduct and service supply chain as Qi et al(2017) argue that supply chain integration (SCI; internal and external), on firm performance focuses on external collaboration than internal collaboration. Therefore, this paperpropose for an effective and efficientcoordination of internal and external functions of SC membersto enhance organizational performance

\subsection{The mediating effect of Supply Chain Collaboration between Value Stream Mapping and Organizational Performance}

Activities of the FPI can be extensively complex as a number of trade-offs need to be made with respect to availability, perishability and variability in supply and quality (Roth et al, 2008, p. 35), and these trade-offs sometimes are difficult to handle because of changes in process output and quality differences (Trienekens et al., 2012). Efficient consumer demand initiative thrives on creating value for the final customers through an efficient value system, and concurrentlyapportion value for the SC partners involved(Christopher, 2005, p. 53).However, poor coordination among SC partners (internal and external) along with inefficient manufacturingpractices have been identified as important factors that affect value creation (quality and waste) in the FPI performance (Dal-Forno et al., 2014; Steur et al., 2016). Wong et al. (2011) noted that internal collaboration o effectively coordinate of all processes and activities of different functional units (such as purchasing, manufacturing, research and development, sales etc.) shipping, inventory and raw material management (Trkman and Groznik, 2006; Feyissa, Sharma and Lai, 2019) within the firm so as to react quickly to changing demands of customers and assist operational performance such as delivery, cost, quality and flexibility (Wong et al., 2011) whereas external collaboration marries a firm's internal processes with external SC partners by developing closer working relationships, integrating processes and sharing information with customers and suppliers (Min et al., 2005; Barratt, 2004; Cao \& Zhang, 2011). SCC has been shown to enable firms to deal with the negative impacts of the misalignment and distortions (bullwhip effect) by reducing waste (inventory fluctuations), quality and becoming more responsive to the whims and changes in customer demands(Göbel et al., 2015).According to Payne, Storbacka, and Frow (2008), effective collaboration in the form of intra and inter firm communication enable different views to be sought regarding issues relating value creation. This is because it incorporate information and knowledge such as customers' wants, ideas and suggestions into the firm's decisions to meet customer expectations. Additionally, SCCaccord firms ample opportunity to learn and acquire knowledge that influence development and application of certain operational strategies such as VSM leading to improved performance (Suarez, Miguel-Davila\& Vasquez, 2016). Intra firm collaboration influence VSM activitiesby identifying and better coordinate other impacted operational teams as well as process segments that are integral to the overall development process and provide leaders, stakeholders and team members with a unified view to enhance performance (Tyagi et al., 2015). 
Moreso, inter-firm collaboration can immensely equip firms within value chain with the needed information and knowledge inthe implementation of standard processes such as identification of problems and waste which may affect performance (Wiese et al., 2015). For instance, Boonsthonsatit \& Jungthawan (2015) argue that VSM considers leanness along the SC making it useful of decision making in leveraging competitiveness which is also key to flexibility as measured in with lead time. The shorter lead time contributes to lower cost, higher profit, and more competitiveness. However, information flow to customer and suppliers no effect on value additions. Gadde and Amani (2016) recommend that managerial actions to waste reduction in food supply can be influenced by the active role ofSC coordination and interactions whileSuarez et al (2016) posit that VSM should provide a holistic understanding on the entire process with respect to roles and contributions tofinished productsthat focus on firms' internal and external chain processes.

\subsection{Discussion}

As markets become more globally connected with an increase rise in new forms of technology and competition, firms need to exploit and adapt to the changes in the business environment (Teece, 2012). Organizations are rooted within supply chain interconnections, with each firm relying on the performance of other firms in the chain (Choi, Dooley, \& Rungtusanatham, 2001; Xu \& Beamon, 2006). According to dynamic capabilities theory (DCT) for industries to survive and attain their full potential under this unpredictable market environment, they need to adopt business strategies that are exceptionally adaptable and flexible in order to seize new opportunities as they arise and to quickly reconfigure activities and organization so as to meet externally generated constraints (Teece, 2000). Dynamic capabilities (DC) further focuses on restructuring, leveraging, learning and knowledge creation, collaboration, sensing as well as seizing (Teece, 2007). Restructuring involves conversion and blending of resources (Bowman \&Ambrosini, 2003); learning and knowledge creation is considered as a foundational capability that allows firms to obtain and use knowledge acquired to renew its capabilities and resource base (Zahra \& George, 2002); collaboration with internal and external socio-technical resources to attain improved performance (Pavlou\&El Sawy, 2011); sensing is the ability to identify prospects in the market environment whereas seizing is the ability to respond timely by taking opportunity to invest in activities which will lead to organizational performance (Kim et al., 2013). Therefore, a strong dynamic capabilities (DC) encourages firms to contest competitors that highlight on efficiency over enhancement, that overlook (or are ignorant of) changing customer expectations or that fail to empower workforce and actors of change (Teece, 2017). Additionally, the relational view (RV) theorizes collaboration as a means of building new capabilities and creating relational rents (Dyer \& Singh, 1998). Specifically, the RV posits that firms will engage in collaborative relationships if they believe that their capabilities will attain and sustained better performance, create efficiencies and synergies through long-term alliances and mutually beneficial relationships (Madhok \& Tallman, 1998; Cao \& Zhang, 2011). Most importantly, if it is assumed that performance enhancement outcomes will be accumulated from such relationships that cannot be achieved by parties in isolation (Dyer \& Singh, 1998; Sambasivan, 2009). For instance Cao and Zhang's (2011) theoretical framework on SCC (internal and external) suggests that collaboration in areas such as information sharing, collaborative communication and joint knowledge creation are critical to performance of firms. Therefore to obtain these advantages, partners must incorporate human and technical resources without the burden of financial ownership (Iyer, Srivastava, \& Rawwas, 2014). The alignment between LM and SCM as DC intends to effect decision making that will result in waste reduction or elimination in the value chain and improve the delivery of quality to customers through systems such as VSM based on SCC (information and knowledge sharing) where all chain memberswill be involved in all the process of value creation by developing a close collaboration within and outside a firm's SC. Further, the study theoretically puts forward a combined practicesSCC from a relational view and examine its effect on operational performance of FPI. 


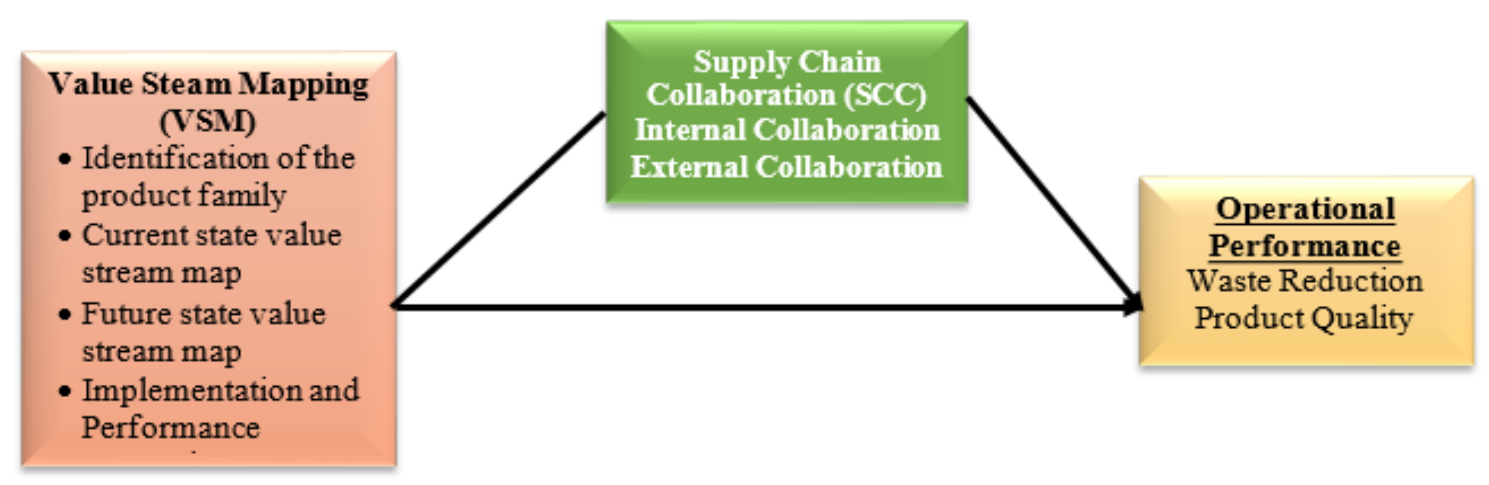

Figure 1: Conceptual Model

\subsection{Conclusion}

The deficiency in studies investigating the generational approach through which VSM can affect operational performance as well as the extant studies on the relationship between VSM and SCC necessitated the need to conduct this study. The objective of this study is to develop a unify framework to discusses how VSM can impact on operational performance through the influence of SCC (internal and external) such as information and knowledge sharing as well as collaborative communication among internal and external SC members in the FPI. Drawing from the experiences and best practices as cited in literature, the framework is to assist practitioners to with a practical strategies as to how to design VSM activities (develop the current state map in order to identify the wastes in the process and action plant to eliminate all the waste store ach the future (better) state) by incorporating internal and external collaborative practices in order to attain improved operational performance in the FPI. Empirically, testing this framework is to further provide appreciative insights from the customer perspective on value addition most importantly to find out the root causes of wastes, which could become the basis for effective coordination and cooperation and adoption of value oriented customer strategies.

\section{References}

Ahmed, M., Jones, E., Redmond, E., Hewedi, M., Wingert, A. \& Gad El Rab, M. (2015). Food production and service in UK hospitals. International Journal of Health Care Quality Assurance, 28, 40-54.

Ali, J. (2016). Adoption of innovative agricultural practices across the vegetable supply chain. International Journal of Vegetable Science, 22 (1), 14-23.

Andam, K \& Asante, S. (2018). Determinants of firm exit and growth in the food processing sector: Evidence from Ghana. INTERNATIONAL FOOD POLICY RESEARCH INSTI, Ghana Strategy Support Program, Development Strategy and Governance Division, Ghana

Andam, K., Al-Hassan, R.M., Asante, S.B. \& Diao, X. (2015). Is Ghana Making Progress in Agro-Processing? Evidence from an Inventory of Processed Food Products in Retail Shops in Accra. Ghana Strategy Support Program (GSSP) Working Paper No. 41. International Food Policy Research Institute. Accra

Andreadis, E., Garza-Reyes, J. A. \& Kumar, V. (2017). Towards a conceptual framework for value stream mapping (VSM) implementation: an investigation of managerial factors. International Journal of Production Research, DOI:10.1080/00207543.2017.1347302

Barratt, M. (2004). Understanding the meaning of collaboration in the supply chain. Supply Chain Management; An international Journal 9 (1), $30-42$

Boonsthonsatit, K. and Jungthawan, S. (2015). Lean supply chain management-based value stream mapping in a case of Thailand automotive industry. 4th International Conference on Advanced Logistics and Transport (ICALT) IEEE, May, 65-69.

Belekoukias, I., Garza-Reyes, J.A. \& Kumar, V. (2014). The impact of lean methods and tools on the operational performance of manufacturing organizations. International Journal of Production Research, 52 (18), 53465366.

Bowman, C. \&Ambrosini, V. (2003). How the Resource-based and the Dynamic Capability Views of the Firm Inform Corporate-level Strategy. British Journal of Management, 14 (4), 289-303. 
Brunt, D. (2000). From current state to future state: mapping the steel to component supply chain. International Journal of Logistics: Research and Applications, 3 (3), 259-271.

Cago, L. (2017). Countries most dependent on others for food. worldatlas.com/articles/the-countries-importing-themost-food-in-the-world.html

Cao, M. \& Zhang, Q. (2011). Supply chain collaboration: impact on collaborative advantage and firm performance. Journal of Operation Management, 29 (3), 163-180.

Choi, Dooley, K. J., \& Rungtusanatham, M. (2001). Supply networks and complex adaptive systems: control versus emergence. Journal of Operations Management, 19(3), 351-366.

Christopher, M. (2005), Logistics and Supply Chain Management, 3rd ed., Pitman, London.

Committee for Economic Development (2017). Economic Contribution of the Food and Beverage Industry. 1530 Wilson Blvd Suite 400 Arlington, VA 22209 202.296.5860

Cui, A.S. and Wu, F. (2016). Utilizing customer knowledge in innovation: antecedents and impact of customer involvement on new product performance. Journal of the Academy of Marketing Science, 44 (4), 516-538.

Dadashnejad A. A. \&Valmohammadi, C. (2018). Investigating the effect of value stream mapping on operational losses: a case study. Journal of Engineering, Design and Technology, 16 (3), 478-500

Dal-Forno, A. J., Pereira, F. A., Forcellini, A. F. \& Kipper, M. L. (2014). Value stream mapping: a study about the problemsand challenges found in the literature from the past 15 years about application of Lean tools. International Journal of Advance Manufacturing Technology, 72,779-790

Dharni, K. \& Rodrigue, R.K. (2015). Supply chain management in food processing sector: Experience from India. International Journal of Logistics Systems and Management 21(1), 115-132

Dora, M., Wesana, J., Gellynck, X., Seth, N. Dey, B. \&Steur, D. H. (2019). Importance of sustainable operations in food loss: evidence from the Belgian food processing industry. Annals of Operations Research. https://doi.org/10.1007/s10479-019-03134-0

Dora, M., Kumar, M., \& Gellynck, X. (2016). Determinants and barriers to lean implementation in food-processing SMEs - a multiple case analysis. Production Planning Control 27, 1-23.

Dyer, J. H., \& Singh, H. (1998). The relational view: Cooperative strategy and sources of inter- organizational competitive advantage. Academy of Management Review, 23(4), 660- 679.

FAO. Save Food: Global Initiative on Food Loss and Waste Reduction; FAO: Rome, Italy, 2018; Available online: http://www.fao.org/save-food (accessed on 1 December 2018).

Fawcett, S. E., Osterhaus, P., Magnan, G. M., Brau, J. C., \& McCarter, M. W. (2007). Information sharing and supply chain performance: the role of connectivity and willingness. Supply Chain Management: An International Journal, 12(5), 358-368.

Feyissa, T.T., Sharma, R. R.K. \& Kuei-Kuei, L. (2019). The impact of the core company'sstrategy on the dimensions ofsupply chain integration. The International Journal of Logistics Management, 30 (1), 231-260

Flynn, B.B., Huo, B. and Zhao, X. (2010). The impact of supply chain integration on performance: a contingency and configuration approach. Journal of Operations Management, 28 (1), 58-71.

Fox, T. \& Fimeche, C. (2013). Global Food: Waste Not, Want Not. Institution of Mechanical Engineers: London, UK.

Gadde, L.E. \& Amani, P. (2016). Food supply in a network context an alternative framing and managerial consequences in efforts to prevent food waste. British Food Journal, 118 (6), 1407-1421

Gan, S. S., Pujawan, I. N., \& Widodo, B. S. (2015). Pricing decision model for new and remanufactured short-life cycle products with time-dependent demand. Operations Research Perspective, 2, 1-12

Garza-Reyes, J.A., Romero, J.T., Govindan, K., Cherrafi, A., Ramanathan, U., (2018). A PDCA-based approach to Environmental Value Stream Mapping (E-VSM). Journal of Cleaner Production, 180, 335-348.

Garza-Reyes, J.A., Villarreal, B., Kumar, V., Molina Ruiz, P.(2016). Lean and Green in the transport and logistics sector - a case study of simultaneous deployment. Production Planning Control 27 (15), 1221-1232.

Göbel, C., Langen, N., Blumenthal, A., Teitscheid, P. \& Ritter, G. (2015). Cutting food waste through cooperation along the food supply chain. Sustainability $7,1429-1445$.

Green, J. C., Lee, J. \&Kozman, T. A. (2010). Managing lean manufacturing in material handling operations. International Journal of Production Research, 48 (10), 2975-2993.

Gupta, S., \& Malhotra, N. (2013). Marketing innovation: A resource-based view of international and local firms. Marketing Intelligence \& Planning, 31(2), 111-126

Halloran, A., Clement, J., Kornum, N., Bucatariu, C., Magid, J.(2014). Addressing food waste reduction in Denmark. Food Policy 49, 294-301.

Han, J., Lu, H., Trienekens, J. and Omta, S. (2013).The impact of supply chain integration on firm performance in the pork processing industry in China. Chinese Management Studies, 7 (2), 230-252. 
Haque, M. \& Islam (2018). Impact of supply chain collaboration and knowledge sharing on organizational outcomes in pharmaceutical industry of Bangladesh. Journal of Global Operations and Strategic Sourcing, 11 (3), 301-320

Hasnan, N. Z. N., Aziz, N. A., Zulkifli, N., \& Taip, F. S. (2014). Food Factory Design: Reality and Challenges Faced by Malaysian SMEs. Agriculture and Agricultural Science Procedia, 2, 328-336. doi:10.1016/j.aaspro.2014.11.046

Hines, P. \& Rich, N. (1997). The seven value stream mapping tools. International Journal of Operation and Production Management, 17, 46-64.

International Trade Centre. (2016). SME Competitiveness in Ghana: Alliances for Action. Geneva: ITC.

Iyer, K., Srivastava, P. and Rawwas, M. (2014). Aligning supply chain relational strategy with the market environment. Journal of Marketing Theory and Practice,22 (1), 53-72.

Jeong, K. B. \& Yoon, T. E. (2016). Improving it process management through value stream mapping approach: a case study. Journal of Information Systems and Technology Management, 13, (3), 389-404

Jeyaraj, K. L., Muralidharan, C., Mahalingam, R., \&Deshmukh, S. G. (2013). Applying value stream mapping technique for production improvement in a manufacturing company: A case study. Journal of The Institution of Engineers (India): Series C, 94(1), 43-52.

Jimenez, E., Tejeda, A., Perez, M., Blanco, J. \&Martinez, E.(2011). Applicability of lean production with VSM to the Rioja wine sector. International Journal of Production Research 50 (7), 1890-904.

Kanyanya, O. (2013). Lean Manufacturing Practices and Performance of Organizations Listed at the Nairobi Securities Exchange, University of Nairobi, Nairobi

Kearney, J. (2010). Food consumption trends and drivers. Philosophical Transactions of the Royal Society B: Biological Sciences, 365(1554), 2793-2807. doi:10.1098/rstb.2010.0149

Kilpatrick, J. \& Osborne, R. (2014). The revolution of lean. Business Breakthrough Inc. Executive White paper, 1-9

Kim, M. \& Chai, S. (2016). Assessing the impact of business uncertainty on supply chain integration. International Journal of Logistics Management, 27 (2), 463-485

Kim, H., Choo, H. J., \& Yoon, N. (2013). The motivational drivers of fast fashion avoidance. Journal of Fashion Marketing \& Management, 17(2), 1361-2026.

Klaus T. (2015). To meet the jobs challenge, maximize the impact of SMEs. World Bank Bloggers

Lehtinen, U., \&Torkko, M. (2005). The Lean concept in the food industry: a case study of a contract manufacturer. Journal of Food Distribution Research, 36(3), 57-67.

$\mathrm{Li}, \mathrm{X}$. (2014). A literature review on value stream mapping with a case study of applying value stream mapping on research process. Texas: Texas A\&M University.

Lovelle, J. (2001). Mapping the value stream. IIE Solutions, 33 (2), 26-33.

Madhok, A., \& Tallman, S. B. (1998). Resources, transactions and rents: Managing value through inter-firm collaborative relationships. Organization Science, 9(3), 326-339.

Manos, T. (2006). Value stream mapping - an introduction. Quality Progress, 39, (6), 64-69.

Min, S., Roath, A. S., Daugherty, P. J., Genchev, S. E., Chen, H., Arndt, A. D., \& Richey, R. G. (2005). Supply chain collaboration: What's happening? The International Journal of Logistics Management, 16(2), 237-256.

Modi, D. B., \& Thakkar, H. (2014). Lean thinking: reduction of waste, lead time, cost through lean manufacturing tools and technique. International Journal of Emerging Technologies and Advanced Engineering, 4(3), 339-344.

Mukherjee, D., H. Bajaj, S. Kowta, and S. Pande (2014). Indian food processing industry: keeping pace with evolving consumer needs. Gurgaon and New Delhi, A.T. Kearney, and Federation of Indian Chambers of Commerce and Industry (FICCI)

Nimeh, H.A., Abdallah, A. B. \& Sweis, R. (2018). Lean supply chain management practices and performance: empirical evidence from manufacturing companies. International Journal Supply Chain Management, 7 (1), 2050-3771

Nowak, M., Pfaff, H. \&Karbach, U. (2017). Does Value Stream Mapping affect thestructure, process, and outcome quality incare facilities? A systematic review. Nowak et al. Systematic Reviews, 6:170

OECD (2017). Small, Medium, Strong. Trends in SME Performance and Business Conditions, OECD Publishing, Paris, http://dx.doi.org/10.1787/9789264275683-en

Ohno, T., 1988. Toyota Production System: Beyond Large-Scale Production. Portland, Oregon:

Productivity Press.

Owoo, N.S., \& Lambon-Quayefio, M.P. (2015). Industries without Smokestacks: The Agro-processing industry in Ghana - Evolution, Public Policy and Contribution to the Ghanaian Economy. A UNU-Wider Project.

Parfitt, J., Barthel, M., \&Macnaughton, S. (2010). Food waste within food supply chains: Quantification and potential for change to 2050. Philosophical Transactions of the Royal Society of London B: Biological Sciences, 365(1554), 3065-3081. 
Pavlou, P. A., \& El Sawy, O. A. (2011). Understanding the elusive black box of dynamic

Payne, A. \& Frow, P. (2014). Developing superior value propositions: a strategic marketing imperative Journal of Service Management, 25 (2), 213-227

Payne A.F., Storbacka, K. and Frow P. (2008), Managing the co-creation of value, Journal of the Academy of Marketing Science, 36, 1, 83-96

Praxiom Research Group Limited (2010). ISO 9000, 9001, AND 9004: Quality Management Definitions

Roth, A., Tsay, A., Pullman, M. \& Gray, J. (2008). Unraveling the food supply chain: strategic insights from China and the 2007 recalls. Journal of Supply Chain Management, 44 (1), 22-39.

Rother, M. \& Shook, J. (1999). Learning to see: value stream mapping to create value and eliminate MUDA, The Lean Enterprise Institute, Brookline, Mass, USA, 1999.

Saboo, A., Reyes, J. A. G., Er, A., \& Kumar, V. (2014). A VSM improvement-based approach for lean operations in an Indian manufacturing SME. International Journal of Lean Enterprise Research, 1(1), 41.

Sambasivan, M., Loke, S.P. \&Abidin-Mohamed, Z. (2009). Impact of knowledge management in supply chain management: a study in Malaysian manufacturing companies. Knowledge and Process Management, 16 (3), $111-123$

Shah S. R. \& Ganji E. N. (2017). Lean production and supply chain innovation in baked foods supplier to improve performance. British Food Journal, 119 (11), 2421-2447

Shah, R., \& Ward, P. T. (2003). Lean manufacturing: context, practice bundles, and performance. Journal of Operations Management, 21(2), 129-149.

Shararah, M.A. (2013). A value stream map in motion. Industrial Engineer, 45 (5), 46-50.

Shou, W., Wang, J., Wu, P., Wang, X., Chong, H.-Y., 2017. A cross-sector review on the use of value stream mapping. International Journal of Production Research, 55(13), 3906-3928.

Shrafat, F. D. \& Ismail, M. (2018). Structural equation modeling of lean manufacturing practices in a developing country context. Journal of Manufacturing Technology Management, 01-59

Steur,H. D., Wesana, J., Dora, M. K., Pearce, D. \& Gellynck, X. (2016). Applying value stream mapping to reduce food losses and wastes insupply chains: A systematic review. Waste Management 58, 359-368

Suarez, M., Miguel-Davila, J.A. \& Vasquez, F. (2016). Supply chain value stream mapping. A new tool of operation management. International Journal of Quality \& Reliability Management, 33 (4), 518-534.

Sun, H., Teh, P. L., \& Linton, J. D. (2019). Impact of environmental knowledge and product quality on student attitude toward products with recycled/remanufactured content: implications for environmental education and green manufacturing. Business Strategic Environment. 27, 935-945.

Tanco, M., Santos, J., Rodriguez, J.L., Reich, J. (2013). Applying lean techniques to nougat fabrication: a seasonal case study. InternationalJournal of Advance Manufacturing Technology, 68, 1639-1654.

Teece, D. J. (2000). Managing Intellectual Capital: Organizational, Strategic, and Policy Dimensions. Oxford: Oxford University Press

Teece. (2007). Explicating dynamic capabilities: the nature and micro foundations of (sustainable) enterprise performance. Strategic Management Journal, 28(13), 1319-1350.

Teece. (2012). Dynamic capabilities: Routines versus entrepreneurial action. Journal of Management Studies, 49(8), 1395-1401

Teece D. J. (2017). Towards a capability theory of (innovating) firms: implications for management and policy. Cambridge Journal of Economics, 41, 693-720

Tortorella, G., Miorando, R. \& Cawley, A.F.M. (2019).The moderating effect of Industry 4.0 on the relationship between lean supply chain management and performance improvement. Supply Chain Management: An International Journal, 24 (2), 301-314

Trienekens, J., Wognum, P., Beulens, A. \& van der Vorst, J. (2012). Transparency in complex dynamic food supply chains. Advanced Engineering Informatics, 26 (1), 55-65.

Trkman, P., \& Groznik, A. (2006). Measurement of Supply Chain Integration Benefits. Interdisciplinary Journal of Information, Knowledge, and Management, 37-45.

Tyagi, S., Choudhary, A., Cai, X. \& Yang, K. (2015). Value stream mapping to reduce the lead-time of a product development process. International Journal of Production Economics, 160, 202-212

Van Wezel, W., Van Donk, D. P. \& G. Gaalman, G. (2006). The planning flexibility bottleneck in food processing industries. Journal of Operations Management, 24 (3), 287-300.

Wang, X., Li, D. \& O'Brien, C. (2009). Optimization of traceability and operations planning: An integrated model for perishable food production. International Journal of Production Research, 47 (11):2865-86.

Whipple, J. M., Lynch, D. F. \&Nyaga, G. N. (2010). A Buyer's Perspective on Collaborative Versus Transactional Relationships. Industrial Marketing Management, 39 (3), 507-518. 
Wiese, A., Zielke, S. \&Toporowski, W. (2015). Sustainability in retailing - research streams and emerging trends. International Journal of Retail \& Distribution Management, 43 (4/5).

Williams, S.C (2013) Customer Satisfaction Measurement In Social Housing: A Review Of The Measures Used By English Housing Associations [online] https://www.researchgate.net/publication/286923863_Customer_Satisfaction_Measurement_in_Social_ Housing_A_Review_of_the_Measures_Used_by_English_Housing_Association

Womack, J.P.(2006). Value stream mapping. Manufacturing Engineering, 136, 145-156.

Wong, C. W. Y., Lai, K., \& Cheng, T. C. E. (2011). Value of Information Integration to Supply Chain Management: Roles of Internal and External Contingencies. Journal of Management Information Systems, 28(3), 161-200.

World Economics Forum (2016). Global challenges on food security and agriculture; annual meeting. http://www.weforum.org/globalchallenges/food-security-and-agriculture/projects/new vision-for-agriculture.

Xu, \& Beamon, B. M. (2006). Supply chain coordination and cooperation mechanisms: an attribute- based approach. Journal of Supply Chain Management, 42(1), 4-12.

Xu, D., Huo, B. and Sun, L. (2014). Relationships between intra-organizational resources, supply chain integration and business performance. Industrial Management \& Data Systems, 114(8), 1186-1206

Yuvamitra, K., Lee, J. \& Dong, K. 2017). Value stream mapping of rope manufacturing: A case study. International Journal of Manufacturing Engineering, 11.

Zahra, S.A. and George, G. (2002). The Net-Enabled Business Innovation Cycle and the Evolution of Dynamic Capabilities. Information Systems Research. 13 (2), 147-150

Zhang, M., Qi, Y., Zhao, X. \&Duray, R. (2015). Mass customization systems: complementarities and performance consequences. International Journal of Logistics Research and Applications, 18(6), pp.459- 475.

Zokaei, K. \& Simons, D. (2006). Performance improvements through implementation of lean practices: A study of the UK red meat industry. International Food and Agribusiness Management Review 9 (2), 30-53. 